\title{
SISTEM INFORMASI SERTIFIKASI BADAN USAHA DAN TENAGA KERJA PADA LEMBAGA PENGEMBANGAN JASA KONSTUKSI PROVINSI NUSA TENGGARA BARAT
}

\author{
(Business Certification And Employment Information Systems In Construction \\ Service Development Institutions Province of West Nusa Tenggara)
}

\author{
Rizki Rahmadi $^{[1]}$, Fitri Bimantoro ${ }^{[1]}$, Muhammad Hadiasri ${ }^{[2]}$ \\ ${ }^{[1]}$ Dept Informatics Engineering, Mataram University \\ J1. Majapahit 62, Mataram, Lombok, NTB, INDONESIA \\ ${ }^{[2]}$ Construction Services Development Institutions \\ Jl. Angsa 1 No. 2A, Mataram, Lombok, NTB, INDONESIA \\ Email: rizrpage@gmail.com, bimo@unram.ac.id, ntb@lpik.net
}

\begin{abstract}
Abstrak
Perkembangan teknologi dari waktu ke waktu begitu pesat sehingga membuat pekerjaan manusia dipermudah dengan adanya teknologi saat ini, dalam perkembangannya, saat ini banyak perusahaan maupun instansi pemerintahan yang menggunakan komputer untuk membantu pekerjaan manusia. Lembaga Pengembangan Jasa Konstruksi Provinsi NTB merupakan salah satu instansi yang menggunakan teknologi sebagai sarana untuk mempermudah tugas dan kewajibannya. Saat ini tugas intansi dalam proses registrasi sertifikasi masih dilakukan secara terpisah pada bagian verifikasinya, sehingga kurang efektif dalam proses sertifikasinya. Dengan adanya permasalahan tersebut, maka dalam pengabdian masyarakat ini dibuatlah sebuah sistem informasi sertifikasi tenaga kerja dan badan usaha berbasis website dengan perancangan sistem menggunakan metode waterfall yang diharapkan dapat membantu pegawai dalam proses pendataan serta pemantauan terhadap proses sertifikasi. Pengujian dilakukan pada pihak Lembaga Pengembangan Jasa Konstruksi Provinsi NTB dengan uji Black-box dan metode Mean Opinion Score (MOS) yang memiliki hasil bahwa 93\% responden setuju bahwa sistem informasi yang dibuat dapat membantu pegawai dan telah berjalan dengan baik.
\end{abstract}

Keywords: Sistem Informasi, Sertifikasi, Website, Black-Box, Mean Opinion Score.

\section{Pendahuluan}

\subsection{Latar Belakang}

Perkembangan teknologi dari waktu ke waktu begitu pesat sehingga membuat pekerjaan manusia dipermudah dengan adanya teknologi saat ini, yang pada umumnya akan diselesaikan dengan cepat. Teknologi merupakan salah satu alat bantu yang sering digunakan pada aktivitas manusia, yang mana perannya begitu penting seperti halnya dalam mendapatkan suatu informasi dengan cepat ataupun mendata suatu informasi. Dari peran ini, teknologi mampu mengolah suatu data dengan efisien dan terstruktur sehingga dapat bermanfaat bagi pengguna teknologi.

Dalam perkembangannya, saat ini banyak perusahaan maupun instansi pemerintahan yang menggunakan komputer untuk membantu pekerjaan manusia. Komputer digunakan untuk mengolah, menyimpan dan mencari data dengan cepat dan efisien sehingga meningkatkan kualitas kerja suatu perusahaan maupun instansi pemerintahan. Lembaga Pengembangan Jasa Konstruksi Provinsi NTB merupakan salah satu instansi yang menggunakan teknologi sebagai sarana untuk mempermudah tugas dan kewajibannya. Lembaga Pengembangan Jasa Konstruksi bertugas untuk melaksanakan registrasi badan usaha kualifikasi menengah dan kecil serta tenaga ahli madya, muda, dan terampil di Provinsi Nusa Tenggara Barat serta mengawasi pelaksanaan proses sertifikasi pada Unit Sertifikasi Badan Usaha dan Tenaga Kerja (USBU dan USTK) yang telah memperoleh lisensi [1].

Dalam proses registrasi sertifikasi masih dilakukan secara terpisah pada bagian verifikasinya, sehingga kurang efektif dalam proses sertifikasinya. Hal ini juga berpengaruh kepada efisiensi dari masing masing bagian pelaksana. Dengan menggunakan sistem yang terpisah, akan menyulitkan pegawai dalam mengelola data-data tersebut, dimana data dari masing bagian harus diperiksa secara manual sehingga akan membutuhkan waktu yang sangat lama. Dengan adanya permasalahan tersebut, maka solusi yang ditawarkan adalah perlu dibuat sebuah sistem informasi sertifikasi yang diharapkan dapat membantu pegawai dalam proses pendataan serta pemantauan terhadap proses sertifikasi. 


\section{TinjauAn Pustaka}

\subsection{Sistem Informasi}

Sistem informasi secara teknis sebagai satuan komponen yang saling berhubungan yang mengumpulkan memproses, menyimpan, serta mendistribusikan informasi untuk mendukung pengambilan keputusan dan kendali dalam suatu organisasi [2].

Pengabdian masyarakat ataupun pemanfaatan hasil penelitian terkait pemanfaatan sistem informasi untuk instansi atau masyarakat banyak digunakan salah satunya Sistem Informasi Absensi Karyawan Pada Lembaga Pengembangan Jasa Konstruksi (Lpjk) Provinsi Aceh [3]. Penelitian lain juga berhasil membuat sistem informasi untuk mencatat penerimaan berkas badan usaha pada LPJK sistem Informasi tersebut dibuat untuk mempermudah user atau pengguna dalam melakukan verifikasi dan validasi berkas sehingga tidak menyulitkan staf dalam pencarian berkas atau dokumen ulang ketika berkas tersebut di butuhkan [4].

\subsection{Sertifikasi}

Sertifikasi merupakan kegiatan Lembaga Pengembangan Jasa Konstruksi untuk memproses penilaian tingkat atau kedalaman kompetensi dalam klasifikasi, kualifikasi dan kemampuan usaha jasa pelaksana konstruksi yang berbentuk usaha orang perseorangan atau badan usaha. Proses dari sertifikasi diawali dengan registrasi sebagai penilaian dan pengakuan formal yang kemudian akan diwujudkan dalam bentuk sertifikat. SBU (Sertifikat Badan Usaha) adalah sertifikat tanda bukti pengakuan formal atas tingkat / kedalaman kompetensi dan kemampuan usaha dengan ketetapan klasifikasi dan kualifikasi [5].

\subsection{Basis Data}

Basis data adalah sumber data yang digunakan secara bersama oleh seluruh pengguna dalam organisasi. Setiap pengguna yang berasal dari fungsi yang berbeda dalam suatu organisasi akan membutuhkan data yang berbeda untuk diguanakan dalam mengerjakan tugasnya sehari-hari [6].

\subsection{Website}

HTML (Hyper Text Markup Language) merupakan pemrograman web yang memiliki sintak atau aturan tertentu dalam menuliskan script atau kode-kode, sehingga browser dapat menampilkan informasi dengan membaca kode-kode HTML.

Website dapat diartikan sebagai kumpulan halaman yang menampilkan informasi data teks, data gambar, data animasi, suara, video dan gabungan dari semuanya, baik yang bersifat statis maupun dinamis yang membentuk satu rangkaian bangunan yang terkait, dimana masing-masing dihubungkan dengan jaringan-jaringan halaman [7].

\subsection{ERD}

Entity Relationship Diagram (ERD) adalah sekumpulan cara atau peralatan untuk mendeskripsikan data-data atau objek-objek yang dibuat berdasarkan dan berasal dari dunia nyata yang disebut entitas (entity) serta hubungan (relationship) antar entitas-entitas tersebut dengan menggunakan beberapa notasi [8].

\subsection{UML}

Unified Modelling Language merupakan alat perancangan sistem yang berorientasi pada objek. UML diagram memiliki tujuan utama untuk membantu tim pengembangan proyek berkomunikasi, mengeksplorasi potensi desain, dan memvalidasi desain arsitektur perangkat lunak atau pembuat program [9].

\subsection{PHP}

PHP atau Hypertext Preprocessor adalah salah satu bahasa pemrograman open source yang sangat cocok atau dikhususkan untuk pengembangan web dan dapat ditanamkan pada sebuah skripsi HTML. PHP merupakan bahasa scripting server - side, dimana pemrosesan datanya dilakukan pada sisi server. Sederhananya, serverlah yang akan menerjemahkan skrip program, baru kemudian hasilnya akan dikirim kepada client yang melakukan permintaan [10].

\subsection{MySQL}

MySQL adalah sebuah perangkat lunak sistem manajemen basis data SQL (bahasa Inggris: database management system) atau DBMS yang multithread, multi-user, dengan sekitar 6 juta instalasi di seluruh dunia. SQL (Structured Query Language) adalah sebuah bahasa yang dipergunakan untuk mengakses data dalam basis data relasional. SQL juga dapat diartikan sebagai antar muka standar untuk sistem manajemen basis data relasional, termasuk sistem yang beroperasi pada komputer pribadi [11].

\subsection{Mean Opinion Scores}

Pengujian MOS (Mean Opinion Scores) digunakan untuk mengetahui respon penilaian secara subjektif dari responden terhadap sistem yang dibuat berdasarkan pengamatan hasil survey, berdasarkan penelitian sebelumnya pada penilaian sistem kepuasan [12] yang menggunakan pengujian MOS mendapatkan hasil uji dengan presentase yang baik dan berpengaruh juga untuk pengembangan sistem kedepannya. 


\section{Metode Pengabdian MASYARAKat}

\subsection{Metode Pelaksanaan Kegiatan}

Pelaksanaan kegiatan dilakukan dengan identifikasi masalah pada instansi terkait, yaitu Lembaga Pengembangan Jasa Konstruksi Provinsi Nusa Tenggara Barat yang akan digunakan untuk membangun sistem informasi sertifikasi badan usaha dan tenaga kerja. Dilakukan juga studi literatur untuk mengetahui bagaimana sistem informasi ini bisa berjalan dengan semestinya, dimana dalam kasus ini penerapan bahasa pemrograman menggunakan PHP utnuk membuat sistem informasi berbasis website dan komponen pendukung dalam menyelesaikan sistem. Pada tahap ini diperlukan juga komunikasi yang bertujuan untuk memahami perangkat lunak yang diharapkan oleh pengguna dan batasan perangkat lunak tersebut. Informasi ini menggunakan metode wawancara, diskusi dan survey langsung. Kemudian informasi dianalisis untuk mendapatkan data yang dibutuhkan oleh instansi terkait yaitu Lembaga Pengembangan Jasa Konstruksi Provinsi Nusa Tenggara Barat.

\subsection{Waktu Kegiatan}

Perencanaan waktu kegiatan adalah selama 2 bulan termasuk waktu untuk persiapan. Beberapa persiapan yang perlu dilakukan sebelum kegiatan pengabdian kepada masyarakat antara lain :

1. Melakukan indentifikasi masalah terkait kebutuhan sistem yang akan didata dengan cara survey bertanya langsung kepada pegawai Lembaga Pengembangan Jasa Konstruksi Provinsi Nusa Tenggara Barat.

2. Menetapkan hari, tanggal kegiatan, tempat serta peralatan yang perlu dipersiapkan untuk pelaksanaan kegiatan pelatihan tersebut.

3. Merancang sistem informasi sertifikasi badan usaha dan tenaga kerja

4. Menerapkan bahasa pemrograman PHP untuk membuat sistem informasi sertifikasi badan usaha dan tenaga kerja berbasis website dan komponen pendukung dalam menyelesaikan sistem

5. Mempersiapkan bahan untuk demonstrasi sistem yang telah dirancang dan dibuat.

6. Melakukan ujicoba data uji pada system yang telah jadi sekaligus pelatihan kepada pegawai LPJK Provinsi NTB.

7. Mempersiapkan feedback dan evaluasi pelatihan dalam bentuk kuisioner yang akan dibagikan kepada pegawai sebagai pengguna aplikasi dan responden

\subsection{Peserta Kegiatan}

Peserta kegiatan dari pelatihan sistem informasi sertifikasi badan usaha dan tenaga kerja Lembaga Pengembangan Jasa Konstruksi Provinsi NTB adalah pegawai pada bidang asesor yang bertugas untuk menaikkan status sertifikasi pada instansi Lembaga Pengembangan Jasa Konstruksi Provinsi NTB.

\section{HaSil dan PEMbahasan}

Sistem informasi sertifikasi Lembaga Pengembangan Jasa Konstruksi Provinsi NTB diperlukan untuk meningkatkan efektifitas dan efisiensi pengelolaan sertifikasi di Lembaga Pengembangan Jasa Konstruksi Provinsi NTB. Kesalahan yang sering dihadapi dalam mengelola data dalam jumlah banyak secara konvensional adalah keamanan, human error dan kesulitan tracking. Untuk itu, fitur yang disampaikan dalam hal ini adalah sebagai berikut :

1. Login

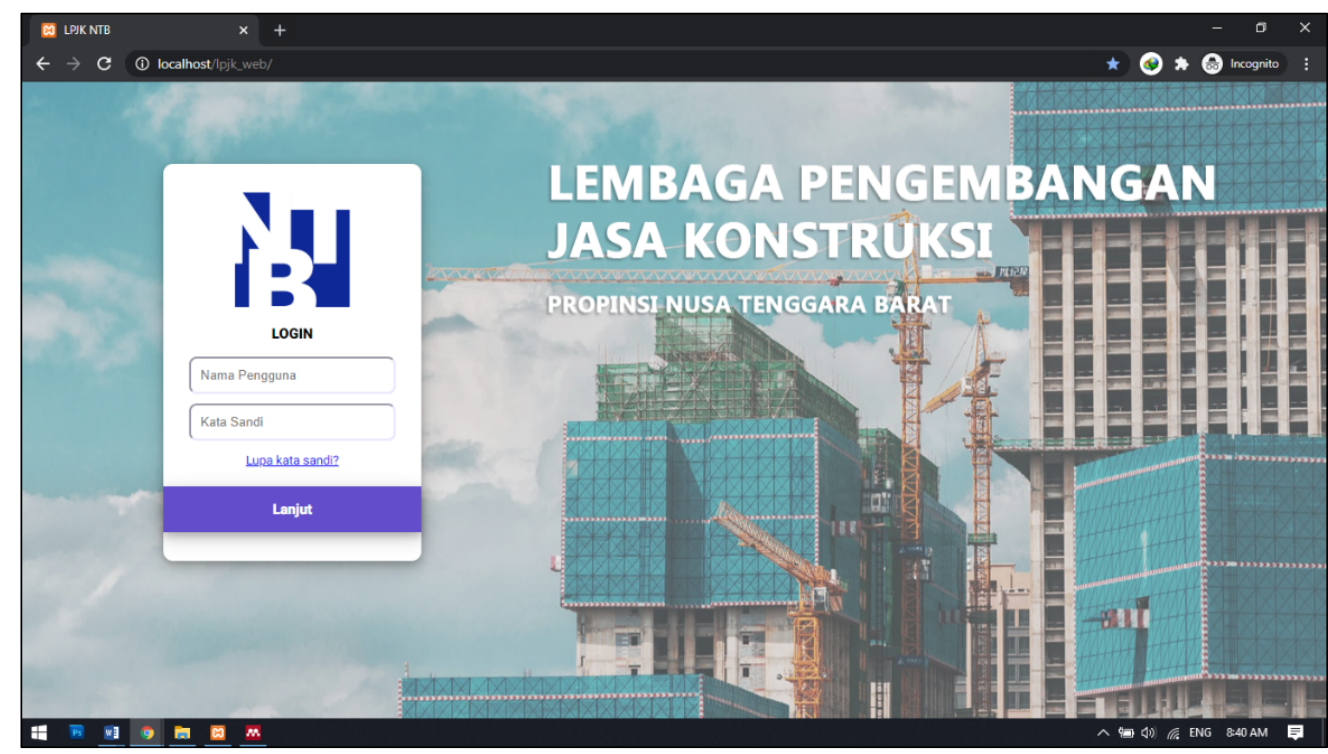

Gambar 11. Implementasi halaman log in 
Gambar 11 merupakan implementasi dari halaman $\log$ in, halaman ini adalah halaman yang pertama kali ditampilkan saat admin membuka sistem informasi sertifikasi badan usaha dan tenaga kerja. Admin perlu memasukkan username dan password yang sesuai pada halaman ini untuk bisa masuk ke dalam sistem.

2. Halaman progres sertifikasi

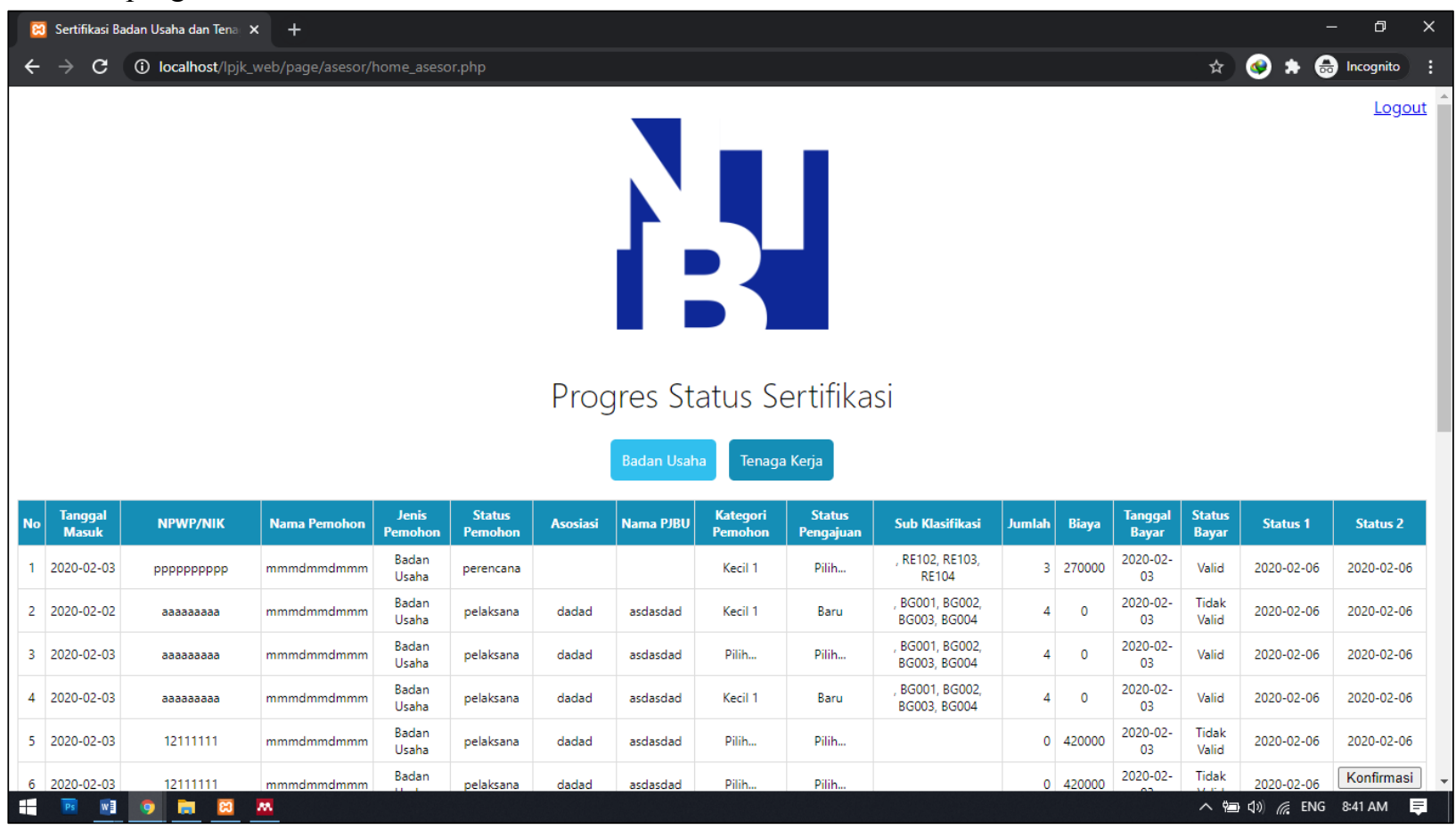

Gambar 12. Implementasi halaman progres sertifikasi

Gambar 12 merupakan implementasi dari halaman progres sertfikasi dalam sistem informasi sertifikasi badan usaha dan tenaga kerja. Halaman ini adalah halaman yang pertama kali ditampilkan setelah pegawai asesor berhasil melakukan $\log$ in.

3. Konfirmasi Perubahan Kenaikkan Status

\begin{tabular}{|c|c|c|c|c|c|c|c|c|c|c|c|c|c|c|c|c|}
\hline No & $\begin{array}{l}\text { Tanggal } \\
\text { Masuk }\end{array}$ & NPWP/NIK & Nama Pemohon & $\begin{array}{c}\text { Jenis } \\
\text { Pemohon }\end{array}$ & $\begin{array}{l}\text { Status } \\
\text { Pemohon }\end{array}$ & Asosiasi & Nama PJBU | & $\begin{array}{l}\text { Kategori } \\
\text { Pemohon }\end{array}$ & $\begin{array}{c}\text { Status } \\
\text { Pengajuan }\end{array}$ & Sub Klasifikasi & Jumlah & Blaya & $\begin{array}{c}\text { Tanggal } \\
\text { Bayar }\end{array}$ & $\begin{array}{l}\text { Status } \\
\text { Bayar }\end{array}$ & Status 1 & Status 2 \\
\hline 1 & $2020-02-03$ & pppppppppp & mmmdmmdmmm & $\begin{array}{l}\text { Badan } \\
\text { Usaha }\end{array}$ & perencana & & & Kecil 1 & Pilih.... & $\begin{array}{l}\text { RE102, RE103, } \\
\text { RE104 }\end{array}$ & 3 & 270000 & $\begin{array}{c}2020-02- \\
03\end{array}$ & Valid & $2020-02-06$ & $2020-02-06$ \\
\hline 2 & $2020-02-02$ & ааааааааа & mmmdmmdmmm & $\begin{array}{l}\text { Badan } \\
\text { Usaha }\end{array}$ & pelaksana & dadad & asdasdad & Kecil 1 & Baru & $\begin{array}{l}\mathrm{BGO01,}, \mathrm{BG} 002, \\
\mathrm{BG} 003, \mathrm{BG} 004\end{array}$ & 4 & 0 & $\begin{array}{c}2020-02- \\
03\end{array}$ & $\begin{array}{l}\text { Tidak } \\
\text { Valid }\end{array}$ & $2020-02-06$ & $2020-02-06$ \\
\hline 3 & $2020-02-03$ & ааааавааа & mmmdmmdmmm & $\begin{array}{l}\text { Badan } \\
\text { Usaha }\end{array}$ & pelaksana & dadad & asdasdad & Pilih.... & Pilih.... & $\begin{array}{l}B G 001, B G 002, \\
B G 003, B G 004\end{array}$ & 4 & 0 & $\begin{array}{l}2020-02- \\
03\end{array}$ & Valid & $2020-02-06$ & $2020-02-06$ \\
\hline 4 & $2020-02-03$ & ааааааааа & mmmdmmdmmm & $\begin{array}{l}\text { Badan } \\
\text { Usaha }\end{array}$ & pelaksana & dadad & asdasdad & Kecil 1 & Baru & $\begin{array}{l}\mathrm{BGO01,}, \mathrm{BG} 002, \\
\mathrm{BG} 003, \mathrm{BG} 004\end{array}$ & 4 & 0 & $\begin{array}{c}2020-02- \\
03\end{array}$ & Valid & $2020-02-06$ & $2020-02-06$ \\
\hline 5 & $2020-02-03$ & 12111111 & mmmdmmdmmm & $\begin{array}{l}\text { Badan } \\
\text { Usaha }\end{array}$ & pelaksana & dadad & asdasdad & Pilih.... & Pilih... & & 0 & 420000 & $\begin{array}{c}2020-02- \\
03\end{array}$ & $\begin{array}{l}\text { Tidak } \\
\text { Valid }\end{array}$ & $2020-02-06$ & $2020-02-06$ \\
\hline 6 & $2020-02-03$ & 12111111 & mmmdmmdmmm & $\begin{array}{l}\text { Badan } \\
\text { Usaha }\end{array}$ & pelaksana & dadad & asdasdad & Pilihn... & Pilih... & & 0 & 420000 & $\begin{array}{c}2020-02- \\
03\end{array}$ & $\begin{array}{l}\text { Tidak } \\
\text { Valid }\end{array}$ & $2020-02-06$ & Konfirmasi \\
\hline 7 & $2020-02-03$ & 12111111 & mmmdmmdmmm & $\begin{array}{l}\text { Badan } \\
\text { Usaha }\end{array}$ & pelaksana & dadad & asdasdad & Pilih... & Pilih.... & & 0 & 420000 & $\begin{array}{c}2020-02- \\
03\end{array}$ & $\begin{array}{l}\text { Tidak } \\
\text { Valid }\end{array}$ & $2020-02-06$ & Konfirmasi \\
\hline 8 & $2020-02-06$ & 99191991 & ivansyah & $\begin{array}{l}\text { Tenaga } \\
\text { Kerja }\end{array}$ & ahli & MCU & Iron Man & Utama & Baru & 206, 208, 210 & 3 & 7500000 & $\begin{array}{c}2020-02- \\
06\end{array}$ & Valid & $2020-02-12$ & Konfirmasi \\
\hline 9 & $2020-02-06$ & 818181818 & Ivan IKI & $\begin{array}{l}\text { Tenaga } \\
\text { Kerja }\end{array}$ & terampil & MCU DC & Tony Stark & Kelas 1 & Baru & , TA003 & 1 & 1000000 & $\begin{array}{c}2020-02- \\
06\end{array}$ & Valid & $2020-02-13$ & Konfirmasi \\
\hline 10 & 2020-02-09 & pppppppppp & mmmdmmdmmm & $\begin{array}{l}\text { Badan } \\
\text { Usaha }\end{array}$ & perencana & Perkumpulan & andi & Kecil 1 & Baru & & 0 & 0 & $\begin{array}{c}2020-02- \\
09\end{array}$ & $\begin{array}{l}\text { Tidak } \\
\text { Valid }\end{array}$ & Konfirmasi & \\
\hline 11 & 2020-02-09 & pppppppppp & mmmdmmdmmm & $\begin{array}{l}\text { Badan } \\
\text { Usaha }\end{array}$ & perencana & Perkumpulan & datuk & Kecil 2 & Baru & S1002, 51003 & 2 & 210000 & $\begin{array}{c}2020-02- \\
09\end{array}$ & Valid & Konfirmasi & \\
\hline 12 & $2020-02-09$ & аааaаaаaаa & mmmdmmdmmm & $\begin{array}{l}\text { Badan } \\
\text { Usaha }\end{array}$ & pelaksana & Perkumpulan & Iron Man & Kecil 2 & Perubahan & , 1003 & 1 & 105000 & $\begin{array}{l}2020-02- \\
09\end{array}$ & Valid & Konfirmasi & \\
\hline
\end{tabular}

Gambar 13. Implementasi halaman penaikkan status

Gambar 13 merupakan implementasi dari halaman profil dalam sistem informasi sertifikasi badan usaha dan tenaga kerja. Halaman ini adalah halaman yang digunakan pegawai untuk mengkonsfirmasi kenaikkan status dengan cara mengklik tombol "konfirmasi" yang terdapat pada kolom status 1 dan status 2 pada tabel progress status sertifikasi. Pada tabel juga dapat dilihat data detail yang diperlukan oleh asesor. 
4. Halaman Admin

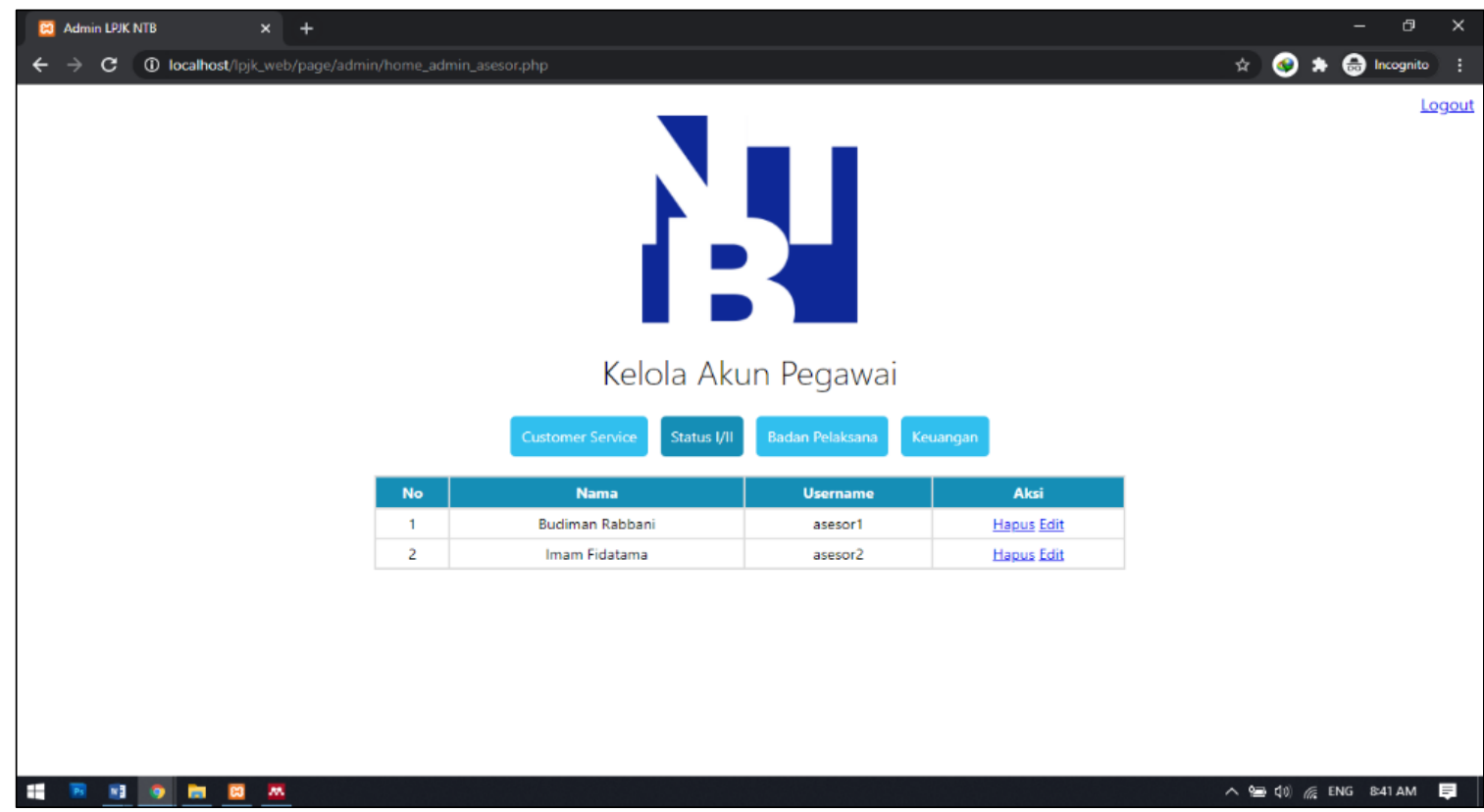

Gambar 14. Implementasi halaman admin

Gambar 14 merupakan implementasi dari halaman admin pada sistem informasi sertifikasi badan usaha dan tenaga kerja. Halaman ini adalah halaman yang digunakan admin untuk mengubah data ataupun menambah data pegawai.

Pemahaman pegawai terhadap teknologi informasi memudahkan dalam pelatihan kerja sistem kepada pegawai Lembaga Pengembangan Jasa Konstruksi NTB. Dengan pengetahuan dasar penggunaan komputer yang baik, diharapkan pegawai dapat mudah adaptasi dengan penggunaan sistem informasi sertifikasi badan usaha dan tenaga kerja yang dibuat, sehingga sistem dapat membantu meningkatkan produktivitas kinerja pegawai karena memudahkan dalam proses pengolahan serta pencarian data.

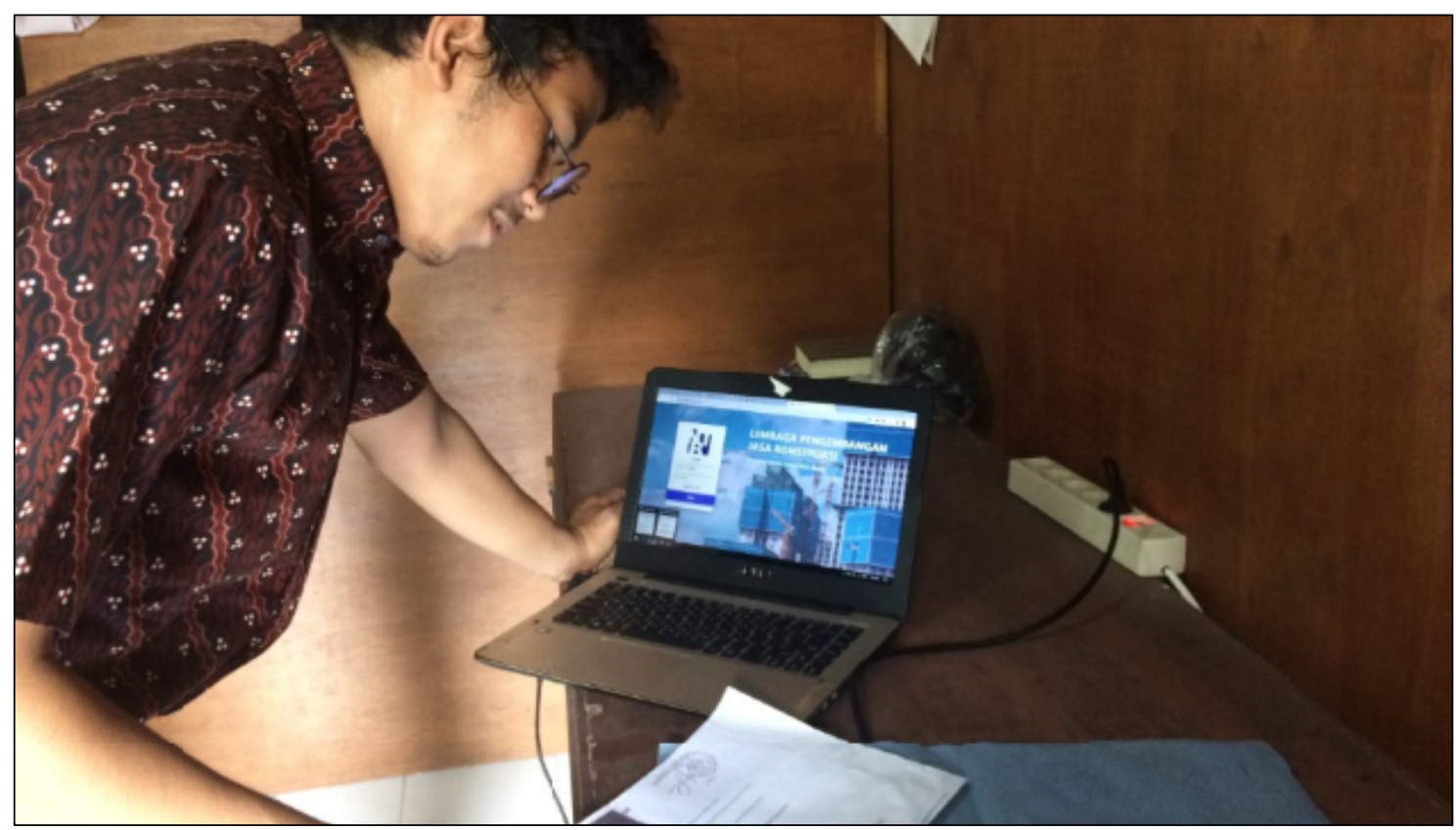

Gambar 15. Sinkronisasi data uji coba pada sistem.

Gambar 15 merupakan dokumentasi pada saat proses sinkronisasi data uji coba pada sistem informasi sertifikasi badan usaha dan tenaga kerja yang dibuat. 


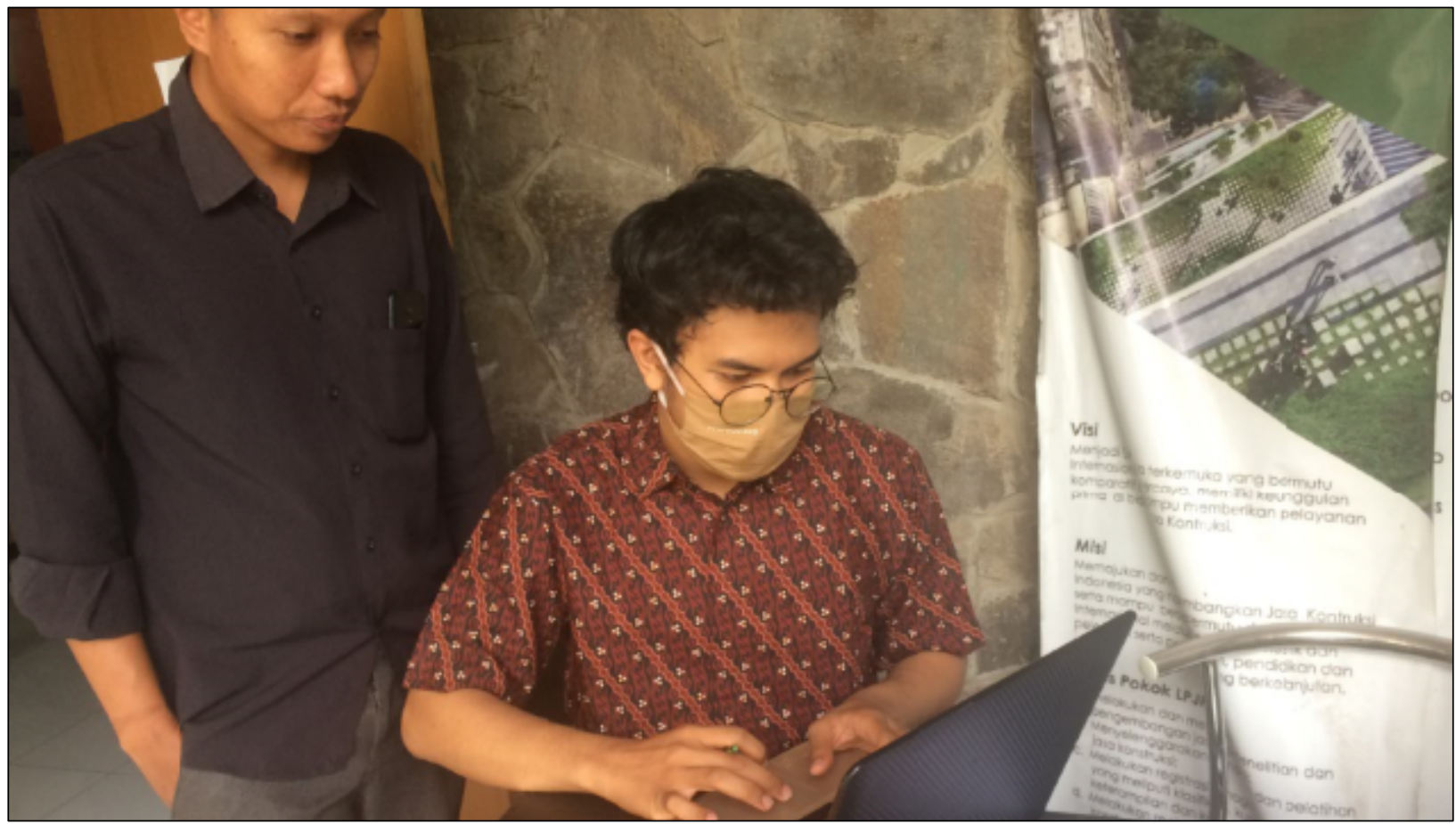

Gambar 16. Pelatihan sistem kepada pegawai

Gambar 16 merupakan dokumentasi pada saat uji coba sistem kepada pegawai dan melakukan pelatihan terhadap penggunaan aplikasi sesuai dengan tugasnya untuk menaikkan status pada proses sertifikasi badan usaha dan tenaga kerja pada Lembaga Pengembangan Jasa Kontruksi Provinsi NTB. Proses uji coba dan pelatihan berjalan lancar dan tidak ada kendala berarti, dikarenakan sebagian besar pegawai juga sudah familiar dengan teknologi informasi dan sudah pernah mengoperasikan computer sebelumnya sehingga dapat cepat beradaptasi pada saat menggunakan sistem informasi yang dibuat pada kegiatan pengabdian masyarakat ini.

Setelah dilakukan implementasi dan pelatihan penggunaan sistem, selanjutnya dilakukan Pengujian MOS (Mean Opinion Scores) digunakan untuk mengetahui respon penilaian secara subjektif dari responden terhadap sistem yang dibuat berdasarkan pengamatan hasil survey [12]. Pengujian ini dilakukan dengan cara mengambil responden yang merupakan pegawai Lembaga Pengembangan Jasa Konstruksi Provinsi Nusa Tenggara Barat bagian asesor dan pegawai yang akan mengatur data-data akun pegawai lainnya.

Pengujian sistem dilakukan dengan menjawab pertanyaan yang diberikan. Parameter pengujian yang digunakan pada metode ini adalah pertanyaan pada Tabel 2. Dari pertanyaan tersebut, responden diminta untuk menjawab dengan mencentang jawaban sesuai dengan ketentuan Mean Opinion Scores sebagai berikut :
1. SS = Sangat Setuju
- Berbobot 5
2. $\mathrm{S}=$ Setuju
- Berbobot 4
3. $\mathrm{C}=$ Cukup
- Berbobot 3
4. $\mathrm{TS}=$ Tidak Setuju
- Berbobot 2
5. STS $=$ Sangat Tidak Setuju $\quad-$ Berbobot 1

Data diolah dengan cara mengalikan setiap poin jawaban dengan bobot yang sudah ditentukan. Dari hasil perhitungan dalam mengalikan setiap bobot jawaban, maka didapatkan hasil nilai jumlah bobot untuk dicari nilai rata-rata jawaban dengan membagi jumlah bobot dengan jumlah responden. Setelah didapatkan nilai rata-rata, kemudian menentukan persentase hasil uji dengan membagi nilai rata-rata jawaban dengan banyaknya pilihan jawaban dikalikan dengan 100.

Berikut hasil pengujian berupa daftar pertanyaan dan hasil perhitungan bobot jawaban dari quisioner yang dilakukan pada masing masing responden yang berjumlah 4 orang yang merupakan pegawai Lembaga Pengembangan Jasa Konstruksi Provinsi Nusa Tenggara Barat bagian asesor dan pegawai yang akan mengatur datadata akun pegawai lainnya : 
Tabel 2. Tabel Mean Opinion Scores

\begin{tabular}{|c|c|c|c|c|c|c|c|}
\hline \multirow{2}{*}{ No } & \multirow{2}{*}{ Pertanyaan } & \multicolumn{5}{|c|}{ Jumlah bobot } & \multirow{2}{*}{ Mean } \\
\hline & & $\mathrm{SS}$ & $\mathrm{S}$ & $\mathrm{C}$ & TS & STS & \\
\hline 1. & Sistem dapat mudah digunakan? & 3 & 1 & 0 & 0 & 0 & 95 \\
\hline 2. & $\begin{array}{l}\text { Sistem memiliki kecocokan terhadap } \\
\text { tampilan warna dan teks yang jelas? }\end{array}$ & 3 & 1 & 0 & 0 & 0 & 95 \\
\hline 3. & $\begin{array}{l}\text { Sistem memiliki navigasi yang } \\
\text { sederhana? }\end{array}$ & 2 & 2 & 0 & 0 & 0 & 90 \\
\hline 4. & $\begin{array}{l}\text { Sistem sudah memenuhi syarat sesuai } \\
\text { dengan proses sertifikasi instansi? }\end{array}$ & 1 & 3 & 0 & 0 & 0 & 95 \\
\hline 5. & $\begin{array}{l}\text { Sistem memudahkan pekerjaan } \\
\text { pegawai? }\end{array}$ & 2 & 2 & 0 & 0 & 0 & 90 \\
\hline & Mean Opinion & cores & & & & & 93 \\
\hline
\end{tabular}

Berdasarkan hasil pengujian MOS yang dilakukan oleh 4 orang responden, pengujian menghasilkan nilai MOS = 93 dari interval 100 yang menunjukkan bahwa Sistem Informasi sistem informasi sertifikasi Lembaga Pengembangan Jasa Konstruksi Provinsi Nusa Tenggara Barat berjalan dengan baik. Adapun grafik hasil perhitungan MOS digambarkan dengan grafik pada Gambar 17.

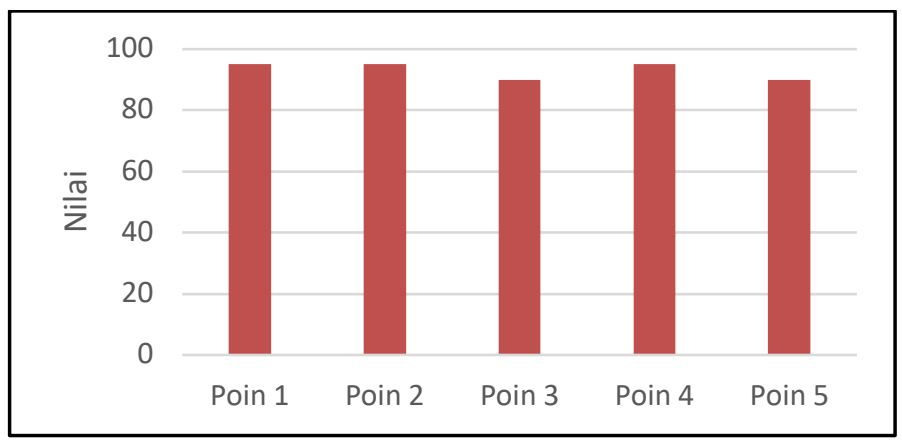

Gambar 17. Grafik hasil pengujian Mean Opinion Score

\section{KESIMPULAN DAN SARAN}

\subsection{Kesimpulan}

Berdasarkan hasil dari pengabdian masyarakat dalam pembuatan sistem informasi sertifikasi berbasis website pada Lembaga Pengembangan Jasa Konstruksi Provinsi Nusa Tenggara Barat dapat disimpulkan bahwa:

1. Pendataan dan Pemantauan progres dari status sertifikasi dapat dilakukan pada Sistem Informasi Sertifikasi Lembaga Pengembangan Jasa Konstruksi Provinsi Nusa Tenggara Barat.

2. Sistem Informasi Sertifikasi Lembaga Pengembangan Jasa Konstruksi Provinsi Nusa Tenggara Barat berjalan dengan baik berdasarkan hasil pengujian yang dilakukan pada pihak LPJK yang mengasilhan nilai Mean Opinion Score sebesar 93\%.

3. Proses uji coba dan pelatihan berjalan lancar dan tidak ada kendala berarti, dikarenakan sebagian besar pegawai sudah familiar dengan teknologi informasi dan sudah pernah mengoperasikan komputer sebelumnya sehingga dapat cepat beradaptasi pada saat menggunakan sistem informasi yang dibuat pada kegiatan pengabdian masyarakat ini

\subsection{Saran}

Berdasarkan sistem informasi sertifikasi berbasis website pada Lembaga Pengembangan Jasa Konstruksi Provinsi Nusa Tenggara Barat yang telah dibuat, penulis menyarankan beberapa hal agar system ini dapat lebih baik lagi kedepannya:

1. Melakukan perbaikan pada tampilan dan menambahkan fitur-fitur baru untuk dapat membuat informasi antar bagian instansi semakin baik dengan menjalin komunikasi yang baik secara daring ataupun tatap muka. 
2. Dengan sistem yang hanya digunakan pada ruang lingkup instansi itu saja, perlu diadakannya penambahan pada fitur keamananya agar sistem dapat lebih aman seperti penggunaan framework dalam pembuatan sistem informasinya.

\section{DAFTAR PUSTAKa}

[1] LPJK Nasional, Peraturan Registrasi Usaha Jasa Pelaksana Konstruksi, 11 a. Jakarta: LPJK, 2008.

[2] Kusnendi, Konsep Dasar Sistem Informasi. 2011.

[3] Nasri, "Sistem Informasi Absensi Karyawan Pada Lembaga Pengembangan Jasa Konstruksi ( Lpjk ) Provinsi Aceh," 2013.

[4] T. H. Ningrum, M. K. G. Umar, and Subhan, "Sistem Informasi Penerimaan Berkas Badan Usaha Jasa Konstruksi pada Lembaga Pengembangan Jasa Konstruksi (LPJK) Provinsi Maluku Utara,” vol. 3, no. 1, pp. 43-51, 2020.

[5] D. Febiharsa, I. M. Sudana, and N. Hudallah, "Uji Fungsionalitas (BlackBox Testing) Sistem Informasi Lembaga Sertifikasi Profesi (SILSP) Batik Dengan AppPerfect Web Test Dan Uji Pengguna," JOINED J., vol. 1, no. 2, pp. 117-126, 2018.

[6] Fathansyah, Basis Data. Revisi Kedua. 2015.

[7] A. Prayitno and Y. Safitri, "Pemanfaatan Sistem Informasi Perpustakaan Digital Berbasis Website Untuk Para Penulis," IJSE, vol. 1, no. 1, 2015.

[8] D. Edi and S. Betshani, “Analisis Data dengan Menggunakan ERD dan Model Konseptual Data Warehouse,” J. Inform., 2012.

[9] S. Dharwiyanti and R. S. Wahono, "Pengantar Unified Modeling LAnguage (UML)," IlmuKomputer.com, pp. 113, 2003.

[10] A. Firman, H. F. Wowor, X. Najoan, J. Teknik, E. Fakultas, and T. Unsrat, "Sistem Informasi Perpustakaan Online Berbasis Web," E-Journal Tek. Elektro Dan Komput., vol. 5, no. 2, pp. 29-36, 2016.

[11] A. Solichin, MySQL Dari Pemula Hingga Mahir. 2010.

[12] B. Irmawati, P. Studi, T. Informatika, F. Teknik, and U. Mataram, "( The Analysis System Students Satisfaction Level Toward Teaching and Learning," vol. 1, no. 1, pp. 31-40, 2019.

[13] Y. Widarahesty, R. Ayu, and E. Soesilowati, "Pemrograman Web," J. Chem. Inf. Model., vol. 5, no. 1, pp. 22 41, 2014.

[14] P. S. Ganney, S. Pisharody, and E. Claridge, Software Engineering. 2013. 